\title{
Gentes groups in the structure of Neolithic cultures of the Central Russian Plain
}

\author{
Yuri B. Tsetlin \\ Institute of Archaeology Russian Academy of Sciences, Moscow, RU \\ yu.tsetlin@mail.ru
}

\begin{abstract}
The possible identification of gentes groups in the Neolithic population of the central Russian plain is presented in this paper. For this purpose, a systematic analysis of pottery decoration traditions was performed. We suggest that all studied archaeological cultures had the same social structure, which included two gentes groups, but the gens also had a core and a periphery.
\end{abstract}

IZVLEČEK - V članku so predstavljeni različni metodološki nastavki za opazovanje skupin s sorodstvenimi vezmi, t.i. gentes, $v$ neolitiku na območju centralnega Vzhodnoevropskega ali Ruskega nižavja. Izdelana je bila sistematična analiza tradicij v izdelavi ornamentov na lončenini. Ugotavljamo, da je imela vsaka arheološka kultura na tem območju enako družbeno strukturo, ki je vključevala dve različni skupini gentes, od katere je vsaka imela še svoje kulturno jedro in obrobje.

KEY WORDS - Neolithic cultures; pottery decoration; social structure; the central Russian plain

\section{Introduction}

It is very difficult to study the social structure of Neolithic communities on the basis of archaeological materials, but circumstances sometimes arise that allow for such an analysis, as was the case in this research. But first the factual basis of this study will be characterised briefly, because the reliability of our conclusions depends directly on its volume.

The analysis included a total of 3600 ceramic vessels from more than 200 excavated Neolithic sites; of these, 10 sites belong to the Volga-and-Oka culture, 32 sites to the Upper Volga culture, 59 sites to the Pit-and-Comb Pottery culture, 47 sites to the Volosovo culture, 20 sites to the Thin Rare-Pit Pottery culture, and 41 sites to the Rare-Pit Pottery culture (Tsetlin 2008.29-33). Although the analysis does not include all the excavated material, we believe that they are adequately representative for our studies in different regions. The Volga-and-Oka culture is not presented in this context, as the pottery assemblage is too small to be statistically relevant.

Analyses of pottery decoration indicate three phases in the developments of the Upper Volga culture (Fig.
1), of the Pit-and-Comb Pottery culture (Fig. 2), and of the Volosovo culture (Fig. 5). We identified two phases in the Rare-Pit Pottery (Fig. 3) and in the Thin Rare-Pit Pottery groups (Fig 4).

The systematic analyses of pottery ornamentation include descriptions of five structural categories: element, pattern, motif, image and composition. Each category is studied separately, but enters as a component in the next. We therefore follow a gradual accumulation of individual features of ornamental traditions in pottery production within a single cultural context. However, our studies of Neolithic ornamental traditions are based mainly on fragmentary pottery assemblages, and therefore the composition of ornaments cannot be studied.

For the study of social structures of Neolithic populations, the structure and proportion of ornamental elements is the most important at the very first level of the analyses, because it provides the most abundant and therefore the most reliable information. We will consider the data consistently for each culture. 


\section{The Upper Volga culture}

The archaeological sites between which the similarity of the pottery ornamentation elements is $80 \%$ or more constitute a cultural core. In the Upper Volga culture, 20 sites (i.e., $62 \%$ from the 32 sites studied) could be defined as core sites. The similarity of the pottery from the core sites and other sites, and also between the other sites, is lower. Moreover, this core is not uniform, since it consists of two groups: group A, which consists of 5 sites, and group
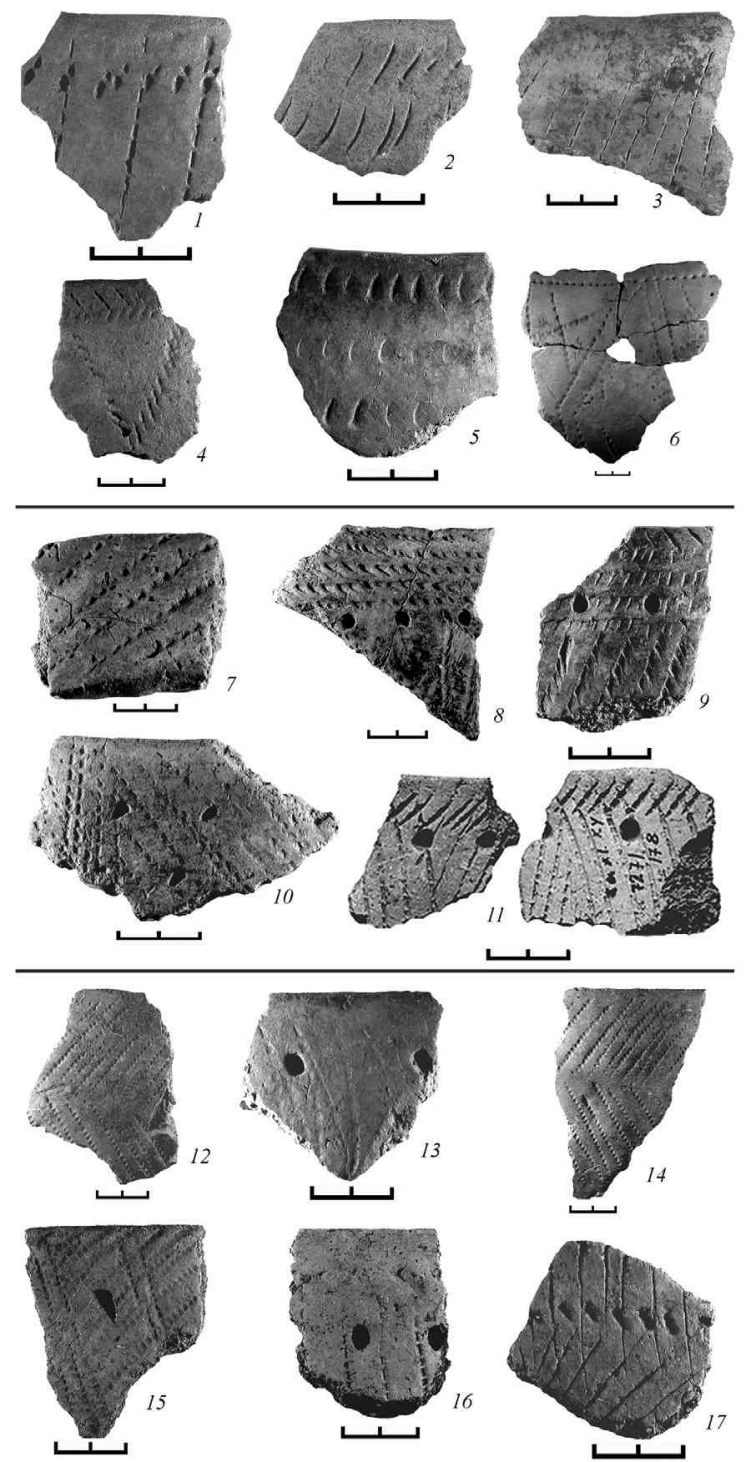

Fig. 1. Upper Volga Pottery culture. Early period (first third of the $5^{\text {th }}$ millennium BC): 1, 2, 4, 5 Vladychinskaya-Beregovaya 1; 3 Vladychinskaya-Borovaya; 6 Vladychinskaya-Beregovaya 2. Middle period (second third of the $5^{\text {th }}$ millennium BC): 7 Sadovyi Bor; 8 Zarech'e 1; 9-10 Maslovo Boloto 2; 1 Sahtysh; 11 Stratigraphic Control Excavation 2 (hereinafter SCE), Horizon 9. Late period (last third of $5^{\text {th }}$ millennium BC): 12-14 Repishe 1; 15-17 Nikolo-Perevoz 1.
$\mathrm{B}$, which consists of 15 sites. The degree of similarity between the sites within each group is approximately $83-84 \%$. Of the remaining 12 sites belonging to this culture, one belongs to group $\mathrm{A}$, and 11 to group B. It is clear that the population of group B dominated the population of the Upper Volga culture.

It is tempting to assume that the distribution of both groups was geographical. However, this could not be clearly observed (Fig. 6). The group B sites were distributed at regular intervals over the region, while the group A sites meet both in the Klyazma River basin and on the Low and Middle Oka basin.

\section{Pit-and-Comb Pottery culture}

In this culture, 34 sites (i.e., $58 \%$ from a total of 59 studied sites) reveal a consecutive degree of similarity of $90 \%$ and more. Unlike the Upper Volga culture considered above, this culture demonstrates much more uniformity in ornamental traditions. However, here again the core of the culture was not uniform, but consisted of two groups. Group A includes 38 sites, among which 19 form the core of the group, and another 19 sites comprise an additional part of the group (the similarity between them and the sites of the core group is notably lower). Group B includes 21 sites, of which 15 form the core of the culture and 6 are additional sites. Within the core of each group, the average similarity between settlements is approximately $92-93 \%$. In this case, group A predominated among the population of the Pit-and-Comb Pottery culture somewhat more than group B.

Let us consider how the sites of each group (A and B) are located on the central Russian plain (Fig. 2). Although group A sites are more concentrated on the southern part of the plain and group B sites to the north, some sites of both groups shared the same territory, for example at the Low Oka River basin.

\section{The Rare-Pit Pottery group}

A total of 41 sites comprise this population group with 30 sites (or $73 \%$ ) forming the core. The degree of similarity between these sites is approximately $90 \%$, which corresponds to the unity of the Pit-andComb Pottery culture sites. As was demonstrated in the previous cases, the core comprises two groups according to the strongest connections. Group A includes 25 core settlements, in which the degree of similarity between the sites is $94 \%$, and 7 additional sites are characterised by weaker connections with- 


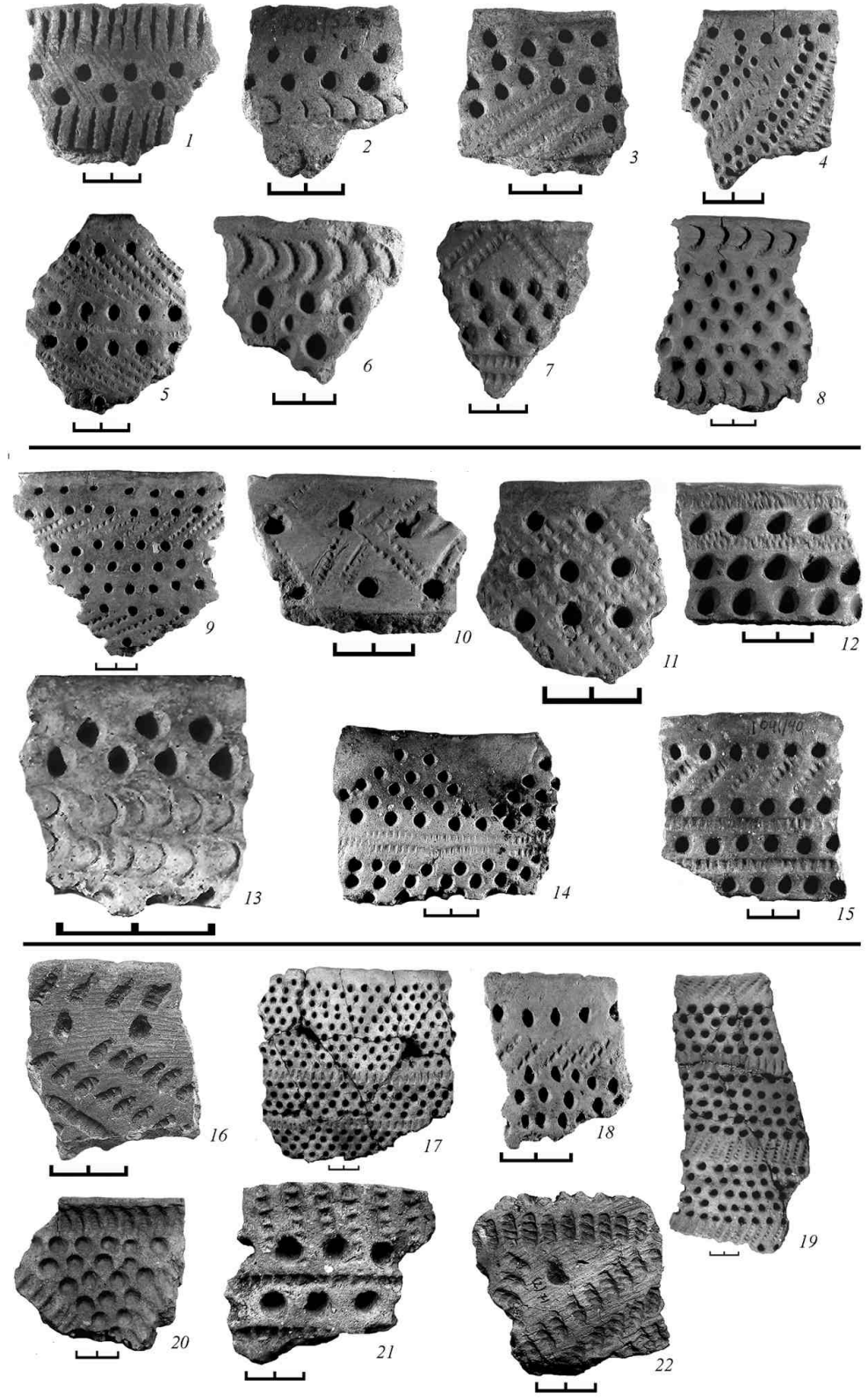

Fig. 2. Pit-and-Comb Pottery culture. Early period last quarter of the $5^{\text {th }}$ millennium BC - last quarter of the $4^{\text {th }}$ millennium $B C$ ): 1 Ivanovskoe 3, SCE-1, Horizon 6; 2-4 Pol'tso 1; 5-6 Gavrilovka 1; 7-8 Plehanov Bor. Middle period (last quarter of the $4^{\text {th }}$ millennium BC - beginning of the $3^{\text {rd }}$ millennium BC): 9 Sadovyi Bor; 10-11 Gavrilovka 2; 12 Vladychinskaya-Beregovaya 1; 13-14 Pol'tso 3; 15 Unitsa. Late period (beginning - second quarter of the $3^{\text {rd }}$ millennium BC): 16 Ivanovskoe 2, SCE-1, Horizon 7; 17-19 Plesheevo 4; 20 Volosovo; 21 Sahtysh 1, SCE-1, Horizon 4; 22 Ivanovskoe 2, SCE-1, Horizon 5.

in this group. Group B includes 9 settlements, and of these 5 belong to the core, with a degree of similarity of approximately $93 \%$. As we can see, group A is more dominant in the population group with RarePit Pottery.

The distribution of settlements with Rare-Pit Pottery of both cultural groups is shown on the map (Fig. 8).
According to this data, the settlements of group A were distributed throughout the region, while B group sites are concentrated at its centre. The settlement patterns are not mutually exclusive within this group.

\section{The Thin Rare-Pit Pottery group}

A total of 20 sites comprise this population group, and 13 (or 65\%) of the sites form the cultural core, since the degree of similarity between the sites is approximately $80 \%$ and more. However, a weaker connection between the settlements in the core group can be observed in comparison with the Pit-and-Comb Pottery culture and the Rare-Pit Pottery group. As in the previous cases, the cultural core of the population with Thin Rare-Pit Pottery is not uniform, and consists of two groups: group A with 16 settlements, 10 of which form the core, while group B includes 4 sites, of which 3 sites present the core. The degree of similarity between the sites in the core group A is $86 \%$ and $91 \%$ between sites in group B. Despite the more compact core in group B, it is possible to conclude that group A predominated among this population.

Let us consider the distribution of settlements of these two groups in the region (Fig. 9). It is clear that the group A settlements extend throughout the territory, while the group B settlements are concentrated around the Yaroslavl Volga basin, with one exception located on the Middle Oka River. Groups A and B do not appear in two separate locations in the distribution pattern.

\section{Volosovo culture}

Among the 47 settlements of this culture, 31 sites (66\%) are characterised by a high degree of similarity of $80 \%$ and more, therefore forming the core of the culture. These sites could also be divided into two groups. Group A includes 22 sites with a degree of similarity of approximately $83 \%$, while a further 
12 sites have weaker ties. Group B consists of 9 highly similar sites (the degree of similarity is $85 \%$ ), forming the core of the group, with 4 additional settlements. Group A predominates in the Volosovo culture population.

The distribution of settlements of both cultural groups on the central Russian plain is shown on the map (Fig. 10). The core of group A is concentrated mainly on the Low and Middle Oka River, while additional settlements also occupy the central part of this territory. In contrast, the core of group B is concentrated in the centre, although some settlements are also located to the south. The two groups are distributed in roughly the same locations on the Russian plain.

As a result, our data on the structure and proportion of ornamental elements of vessels permits us to draw the following conclusions. Firstly, each archaeological culture is structured into the cultural core with strong relations between settlements, and the cultural periphery with weaker ties between settlements. On average, a cultural core includes some $65 \%$ of settlements and the cultural periphery comprises some $35 \%$ of sites. Secondly, each archaeological culture consists of two cultural population groups with specific ornamental traditions, as will be demonstrated later, in which one is dominant and the other recessive. Thirdly, the cultural core and cultural periphery could be identified in each of the population groups. Fourthly, judging by the spatial distribution of the cultures and cultural groups within them the populations of these did not live separately in different regions in the strict sense, but inhabited the same territory.

Next we present the basic features of the ornamental traditions within each archaeological culture or large population group in the central Russian plain.

\section{The Upper Volga culture}

Ornamental elements. We begin with a comparative analysis of the structure and proportion of ornamental elements on the pottery of both groups
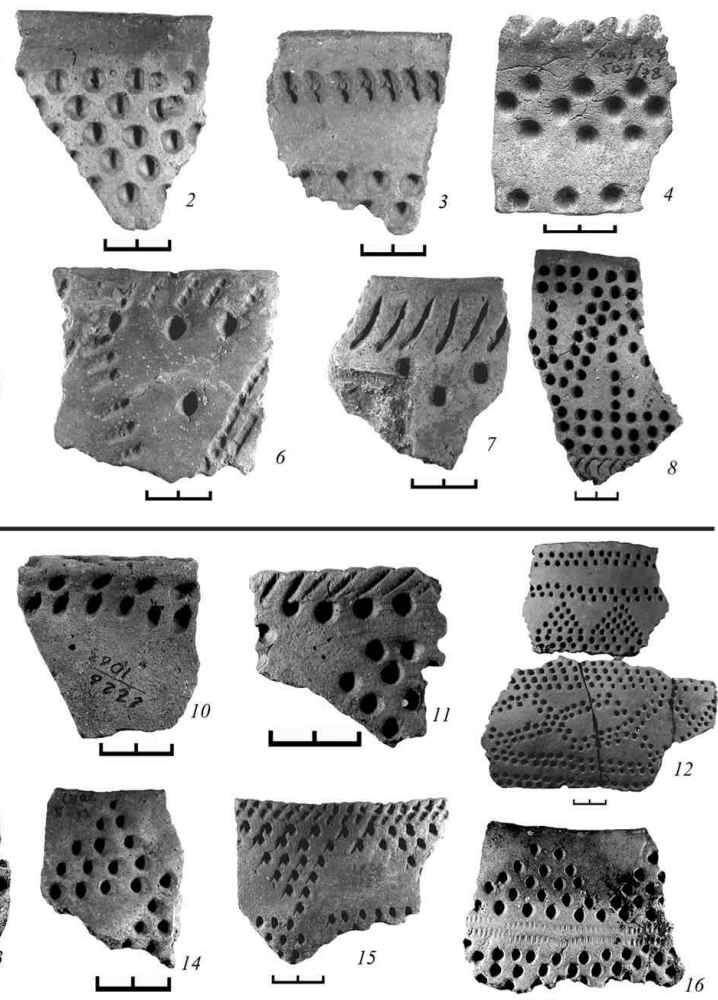

-

Fig. 3. The Rare-Pit Pottery group. Early period (third quarter of the $4^{\text {th }}$ millennium BC): 1 Panfilovskaya; 2-3 Plehanov Bor; 4 Sah1, SCE-2, Horizon 6; 5 Sahtysh 8, SCE-1, Horizon 5; 6-7 Repi lennium BC - beginning of the 3rd millennium BC): 9 Fefelovskaya Pridorozhnaya; 10 Shagara 2; 11 Maslovo Boloto 2; 12 Zarech'e 1; 13 Berendeevo 1, SCE-1, Horizon 3; 14-15 Pol'tso 1; 16 Pol'tso 3.

belonging to this culture. For the traditions of group A, undecorated parts on the surface of vessels (54\%) and rarer dot decoration $(21 \%)$ are the most typical ornamental elements. The traditions of the dominant group B were much more varied. Here, the potters equally used a comb ornament $(22 \%)$ in combination with empty areas on the surfaces (23\%). Pit and dot elements of decoration were less common ( $17 \%$ each), as were pin elements (14\%). The general degree of similarity of traditions of these two groups in terms of ornamental elements is $65 \%$.

Ornamental patterns. A different picture can be observed in the analysis of patterns of ornamentation. The potters used mainly dot patterns (group A - 58\%, group B - 35\%), while comb (group A $21 \%$, group B - 33\%) and pin (group A - $21 \%$, group B - 24\%) patterns were used somewhat less. The similarity of the traditions of these groups in terms of ornamental patterns is $77 \%$, i.e., somewhat more than in terms of ornamental elements. Thus, both groups of the Upper Volga culture were quite similar in terms of the use of ornamental elements and patterns on ceramic vessels. 

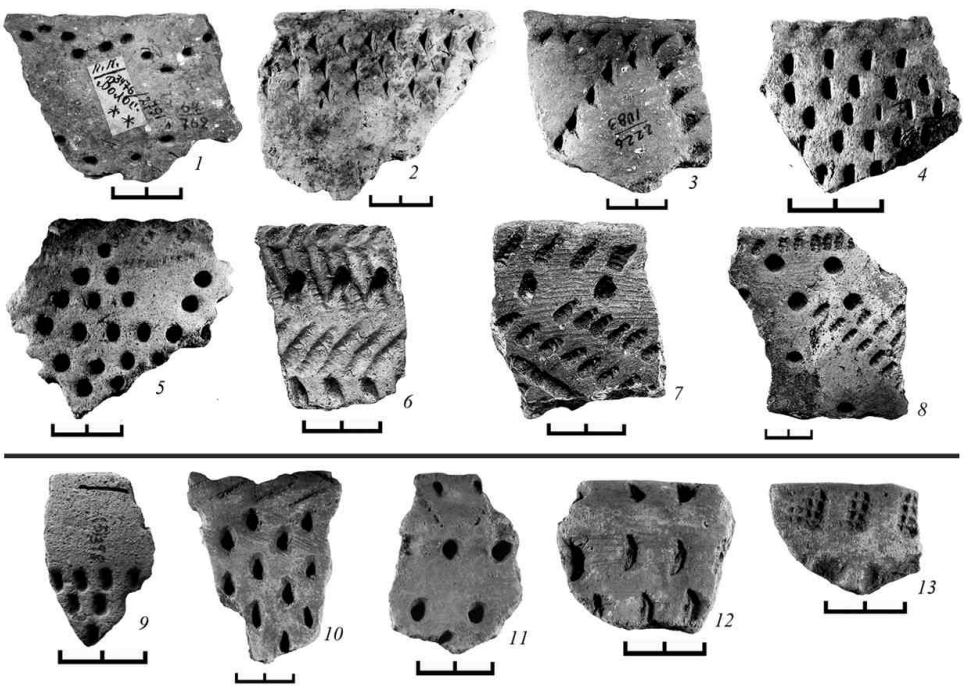

Fig. 4. The Thin Rare-Pit Pottery group. Early period (second quarter - the end of the $4^{\text {th }}$ millennium BC): 1-2 Volosovo; 3 Shagara 2; 4 Maslovo Boloto 2; 5 Unitsa; 6-8 Ivanovskoe 2, SCE-1, Horizon 7. Late period (the end of the $4^{\text {th }}$ millennium BC - the end of the $3^{\text {rd }}$ millennium BC): 9 Ivanovskoe 3, SCE-1, Horizon 5; 10-13 Fefelovskaya Pridorozhnaya.

Ornamental motifs. The distribution of simple ornamental motifs is practically the same as the distribution of ornamental elements, so they are not considered here.

In contrast, 9 kinds of complex motifs in the pottery group A and 22 variants in group B could be identified. The degree of similarity between the groups is only $36 \%$ according to these features. However, only a few of these motifs were present on a larger number of finds in this culture. In group A, these motifs are: a dot pattern with parts without ornamentation between them (41\%), two kinds of alternate comb patterns divided by parts without decoration (25\%), and two kinds of alternating dot patterns (16\%). In group B, the most abundant motifs are: alternate pit and comb elements (13\%), two kinds of alternating comb pattern (12\%), and two alternating dot patterns (11\%). The motifs in group B are much more varied than those in group $\mathrm{A}$; there are no predominant motifs and the mass motifs of both groups are different, except one which shows that the histories of each group were quite different.

Ornamental images. Simple images were more widespread in the ornamental traditions of the Upper Volga culture, and complex (combined and crossed) images were used rarely. The simple images consist of two adjoining motifs that include only the same kinds of ornamental elements or patterns. In group A, 15 such images could be identified, and in group B, 19 of the images could be termed simple.
In both groups, only 5 combinations of images are present in more than $10 \% ; 3$ of these combinations are present in both group A and B, while the remaining 2 combinations are present in only one of the groups (Tab. 1).

The absence of obviously predominant images in the pottery decorations and the lower degree of similarity between the two groups in terms of simple ornamental images (49\%) is quite interesting since it correlates with the results of the analysis of ornamental motifs.

In the complex images consisting of different combinations of motifs, 5 variants of these images could be identified, including 4 variants in group A and only one in group B (Tab. 2). The degree of similarity between the groups is only $25 \%$.

To sum up the comparative analysis of ornamental stylistic traditions, the two groups of the Upper Volga culture have similar ornamental elements and patterns in the pottery, but are considerably different in terms of ornamental motifs and images.

\section{Pit-and-Comb Pottery culture}

Ornamental elements. In group A, three different ornamental elements are present: the pit (41\%) and comb element (26\%) as well as an element without decoration (15\%). In group B, only the pit (60\%) and comb (25\%) ornamental elements are present. The degree of similarity of the ornamental elements is approximately $76 \%$.

Ornamental patterns. In group A, 8 kinds of ornamental pattern could be identified, with the comb

\begin{tabular}{|l|c|c|c|}
\hline & Motifs & Group A & Group B \\
\hline pit & comb & & 16 \\
\hline pit & dot & 13 & \\
\hline pit & without ornamentation & & 17 \\
\hline comb & comb & 16 & 11 \\
\hline comb & dot & 12 & \\
\hline pomb & without ornamentation & 16 & 13 \\
\hline
\end{tabular}

Tab. 1. The percentages of simple ornamental images on the Upper Volga culture pottery. 
(49\%) and pit (25\%) decoration elements being the most common. There are 5 kinds of patterns in group B: comb (55\%), pit (15\%), sickle-shaped (14\%) and grooved decoration (13\%). The degree of similarity of the two groups is quite high at approximately $82 \%$.

Ornamental motifs. In group A, 22 variants of the complex combined motifs could be identified, of which 3 predominate: the motif of two alternating comb patterns (32\%), the motif of pit patterns alternating with parts without ornamentation (14\%), and the motif of alternating pit and comb patterns $(12 \%)$. In group B, 9 variants of such motifs were identified, 3 of which were predominant: the motif of two alternating comb patterns (36\%), the motifs of two alternating pit patterns $(17 \%)$ and of two alternating patterns including various grooved ornamental elements (11\%). The degree of similarity between these two groups is $54 \%$.

In the complex crossed ornamental motifs, 14 variants were identified in group A, the two most common being crossed pit and comb elements $(54 \%)$ and the motif of two various crossing comb elements (16\%). In group B, 9 variants of complex crossed ornamental motifs were identified, but only one predominates crossed pit and comb elements (81\%). The general degree of similarity of these groups is $67 \%$.

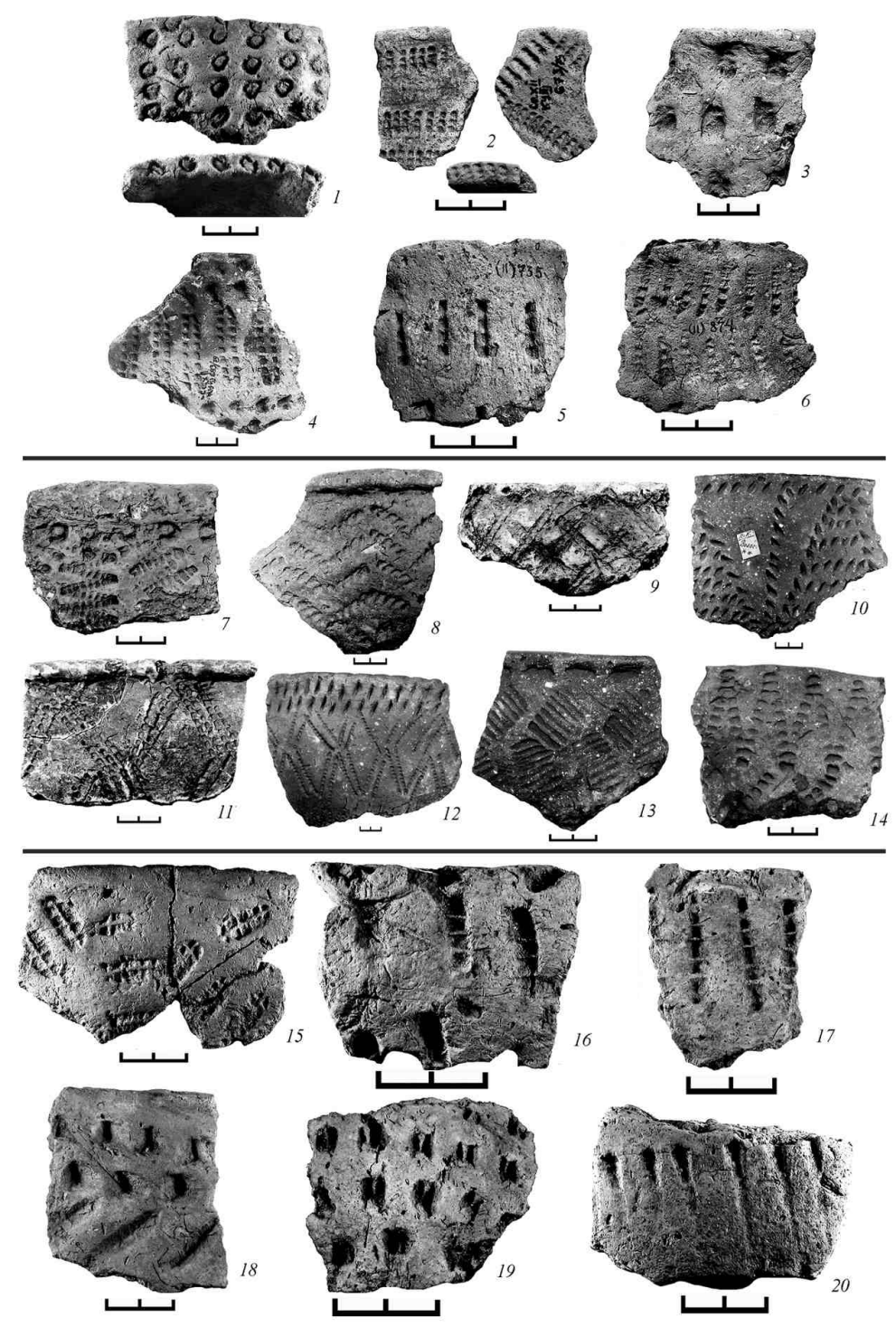

Fig. 5. Volosovo Pottery culture. Early period (last quarter of the $4^{\text {th }}$ millennium BC - beginning of the $3^{\text {th }}$ millennium BC): 1 Maslovo Boloto 2; 2-3 Sahtysh 2, SCE-2, Horizon 1; 4-6 Sahtysh 2, SCE-2, Horizon 17. Middle period (beginning - third quarter of the $3^{\text {rd }}$ millennium BC): 7-9, 11 Volodary; 10, 12-14 Volosovo. Late period (last quarter of the $3^{\text {rd }}$ millennium BC - beginning of the 2nd millennium BC): 15-19 Plesheevo 4; 20 Vashutino 1, SCE-1, Horizon 4.
Ornamental images. Here, simple images are represented by fewer variants: 12 in group $A$ and 10 in group B. Group A includes 3 simple images: pit and comb motifs (51\%), pit motif and an area without ornamentation (15\%), and sickle-shaped motif $(11 \%)$. In group $\mathrm{B}$, two variants of the images predominate: pit and comb motifs (51\%) and pit and sickle-shaped motifs (19\%). The similarity of the two groups of Pit-and-Comb Pottery culture is $85 \%$ in terms of simple ornamental images, which was unexpected in comparison with the data from the Upper Volga culture.
Ornamental images consisting of complex combined motifs in group A occur in 30 variants, but only one predominates (36\%) among them. In group B, complex combined motifs comprise only 14 variants, 4 of which are most frequent (Tab. 3). The degree of similarity of ornamental images between the two groups from Pit-and-Comb Pottery culture is only $41 \%$.

There were 23 images of crossed motifs in group A and 15 images in group B. In both groups, two ornamental images predominate: the pit motif and the motif with crossed pit and comb elements $(26 \%$ in 


\begin{tabular}{|l|c|c|c|}
\hline \multicolumn{2}{|c|}{ Motifs } & Group A & Group B \\
\hline comb & two dot patterns & 16 & \\
\hline pin & $\begin{array}{c}\text { pin patterns and parts } \\
\text { without ornamentation }\end{array}$ & 40 & 13 \\
\hline without ornament & $\begin{array}{c}\text { dot patterns and parts } \\
\text { without ornamentation }\end{array}$ & 17 & \\
\hline $\begin{array}{l}\text { dot patterns and } \\
\text { parts without ornament }\end{array}$ & $\begin{array}{c}\text { dot patterns and parts } \\
\text { without ornamentation }\end{array}$ & 16 & \\
\hline
\end{tabular}

Tab. 2. The percentages of complex ornamental images on the Upper Volga culture pottery.

group A, $15 \%$ in group B), and the comb motif with a motif of crossed pit and comb elements $(20 \%$ in group A, $48 \%$ in group B). The degree of similarity of the two cultural groups in terms of this parameter is $52 \%$.

As we can see, the ornamental traditions of the predominant group A are stylistically more varied than the traditions in group B, and both groups have a high degree of similarity in ornamental elements, patterns and simple images (76-82\%), although the similarity of motifs, combined and crossed ornamental images is only $40-60 \%$.

\section{The Rare-Pit Pottery group}

Ornamental elements. In this population group we identified two cultural groups with some differences in their ornamental traditions. In group A, 9 different ornamental elements were used; the pit element (42\%) and element without ornament (40\%) being the most common. In group B, 6 ornamental elements were used, 3 of them being predominant an element without ornament (44\%), pit (23\%) and irregular pit elements (21\%). The degree of similarity between the ornamental elements is quite high at $74 \%$.

Ornamental patterns. In group A, 6 types of ornamental pattern were used, but the pit ornamental elements $(84 \%)$ were the most common. In group B, there were 3 types of pattern, with the pit $(61 \%)$ and irregular pit $(28 \%)$ patterns being the most common. The degree of similarity between the groups is $74 \%$.

Ornamental motifs. In the two groups, A and B, 12 and 6 variants of motifs could be identified respectively. In group $\mathrm{A}$, the simple pit pattern $(11 \%)$, the complex combined motifs of two alternating is $36 \%$. the Pit-and-Comb Pottery. pit patterns $(17 \%)$ and a pit pattern alternating with areas without ornamentation $(53 \%)$ were the most common. In group $\mathrm{B}$, two simple motifs had been made with pit $(15 \%)$ and comb (11\%) patterns, and two complex combined motifs were used, one consisting of two pit patterns (36\%) and the other with irregular pit patterns alternating with areas without ornamentation (28\%). The degree of similarity between the groups is $40 \%$.

Ornamental images. Simple images are represented by 13 variants in group A and 7 in group B. The pit motif and an area without ornamentation are the most common images in both groups $(74 \%$ in group A and $72 \%$ in group B). The degree of similarity between the two groups is $82 \%$.

Only the complex combined motifs were identified in the pottery of both groups, with 20 variants in group $A$ and 8 variants in group B. The pit motif and motif consisting of two alternating pit patterns $(17 \%)$, and the pit motif and motif of a pit pattern divided by areas without ornamentation (42\%) were the most common in group A. In group B, the following 3 images are the most common: the pit motif and the motif of two different pit patterns (25\%), the image of irregular pit motif and motif of irregular pit patterns divided by areas without ornamentation (38\%), and an image consisting of a empty area and a motif of two alternating pit patterns (20\%). The degree of similarity between the groups

As we can see from these data, the ornamental traditions of the dominant group A were more varied than those of group B. Additionally, the cultural unity of groups A and B would be reflected in elements, patterns, and simple images (74-82\%), and their cultural differences were developed in motifs and complex ornamental images.

\begin{tabular}{|l|c|c|c}
\hline \multicolumn{2}{|c|}{ Motifs } & Group A & Group B \\
\hline pit & two pit patterns & & 14 \\
\hline pit & pit patterns and parts without ornamentation & & 12 \\
\hline pit & two comb patterns & 36 & 28 \\
\hline comb & $\begin{array}{r}\text { two comb patterns and } \\
\text { parts without ornamentation }\end{array}$ & & 11 \\
\hline
\end{tabular}

Tab. 3. The percentages of images consisting of combined motifs on 


\section{The Thin Rare-Pit Pottery group}

Ornamental elements. In group A, 9 types of ornamental element were identified, with the irregular pit $(27 \%)$, comb (11\%) ornamentation and pottery without ornamentation (39\%) being the most common in the assemblages. In group B, 6 ornamental elements were identified, with the pit (47\%), grooved (15\%) ornamentation and pottery without ornamentation (34\%) being the most common. The degree of similarity between the groups is $53 \%$.

Ornamental patterns. Only 4 ornamental patterns were used in group A, with the irregular pit (67\%) and the pit pattern (22\%) being the most common. In group B, 3 patterns were used; the most common are the pit (65\%), irregular pit (20\%) and pin pattern $(15 \%)$. The degree of similarity between the groups is approximately $51 \%$.

Ornamental motifs. In group A, 2 variants of simple and 6 variants of complex combined motifs were identified, and in group B, 5 variants of complex combined motifs were identified. Four variants of motifs (Tab. 4) were present in each groups. The degree of similarity between the two groups is $53 \%$.

Ornamental images. In group A, 12 types of simple and 8 types of complex ornamental images consisting of combined motifs were identified. In group B, only 6 various simple images and 8 complex images were identified. In total, simple ornamental images in both groups considerably prevailed over complex images, with $67 \%$ and $85 \%$, respectively.

We identified 3 simple images in group $\mathrm{A}$ and 4 simple images in group B (Tab. 5), and 3 complex images in group A and 6 complex images in group B (Tab. 6). The degree of similarity between the two groups in terms of simple images is $33 \%$, and the similarity in terms of the complex images is $31 \%$.

Thus, we conclude that the dominant group A had more varied ornamental traditions with regard to various stylistic features. The degree of similarity between the two groups of this population is much lower than in other cultures, which shows that the identified culture was less homogeneous. At the same time, some features are common to most cultures, which developed from the affinity of cultural groups. These features become apparent in the fact that the maximum affinity of groups A and B is identified in elements (53\%), patterns (51\%), and motifs (53\%), and the lowest percentage is identified in ornamental images of pottery (33\% and $31 \%)$.

\section{Volosovo culture}

Ornamental elements. In group A, 10 variants of ornamental elements were identified, and in group $\mathrm{B}, 8$ variants were identified; 4 variants of the elements were present in both groups. In group A, the

Fig. 6. The Upper Volga culture settlements. Group A: 1 - Core settlements: 14 Fefelov Bor; 30 Sahtysh 1, SCE-1, Horizon 8; 32 Sahtysh 2, SCE-1, Horizon 9; 34 Sahtysh 8, SCE-1, Horizon 6; 41 Ivanovskoe 7, SCE-2, Horizon 6. 2 - Peripheral settlement: 2 Gavrilovka 2. Group B: 3 - Core settlements: 13 Odoevskie fermy; 16 Shagara 1; 16a Shagara 2; 17 Vladychinskaya-Beregovaya 1; 18 Vladychinskaya-Beregovaya 2; 19 Vladychinskaya-Borovaya; 24 Biserovo ozero; 31 Sahtysh 1, SCE-2, Horizon 11; 31a - Sahtysh 1, SCE-2, Horizon 9; 32 Sahtysh 2, SCE-1, Horizon 7; 38 Ivanovskoe 3, SCE-1, Horizon 9; 41 Ivanovskoe 7, SCE-2, Horizon 3; 42 Berendeevo 1, SCE-1, Horizon 7; 45 Pol'tso 2; 53 Yazykovo 1, SCE-2, Horizon 10. 4 Peripheral settlements: 1 Gavrilovka 1; 8 Sadovyi Bor; 22 Bogdarnya;

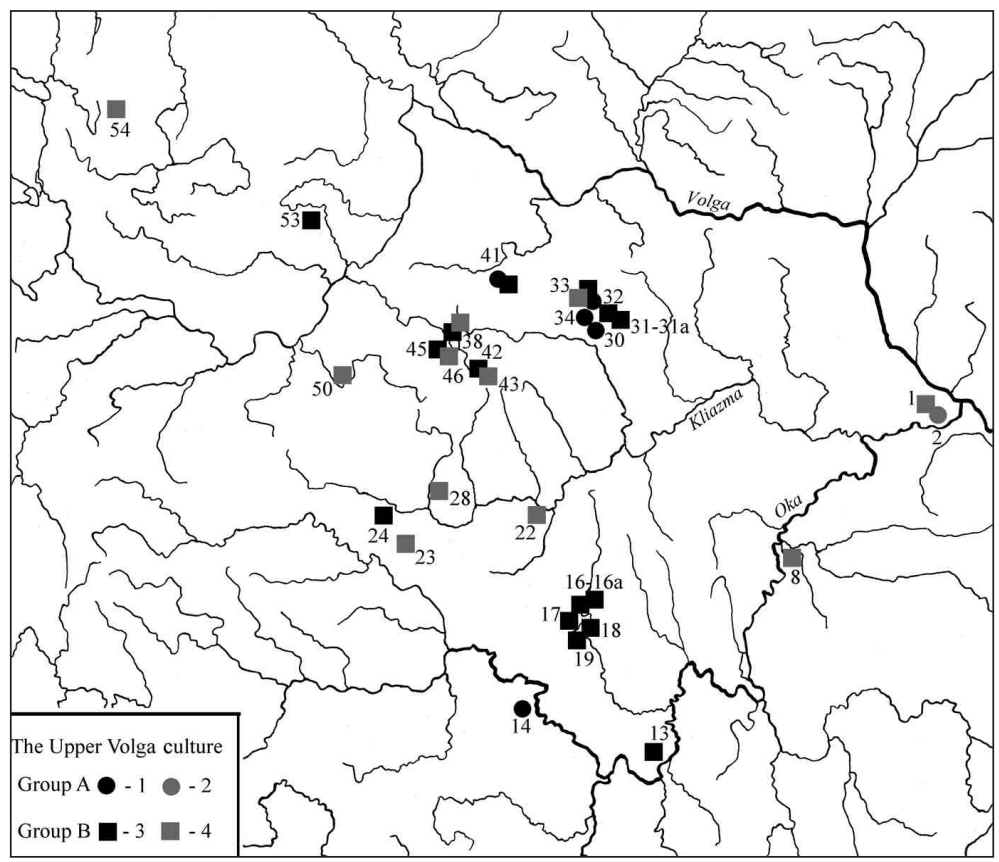
23 Maslovo Boloto 2; 28 Zarech'e 1; 33 Sahtysh 2, SCE-2, Horizon 20; 38 Ivanovskoe 3, SCE-1, Horizon 6; 43 Berendeevo 2a, SCE-21, Horizon 2; 46 Pol'tso 3, Nikolo-Perevoz 1; 54 Repishe 1. 


\begin{tabular}{l|c|c} 
Motifs & Group A & Group B \\
\hline irregular pit patterns & 12 & \\
\hline two alternating pit patterns & 16 & 35 \\
\hline pit pattern and parts without ornamentation & & 25 \\
\hline $\begin{array}{l}\text { two alternating irregular pit patterns } \\
\text { without ornamentation }\end{array}$ & 22 & 28 \\
\hline $\begin{array}{l}\text { two alternating pin patterns, divided by parts } \\
\text { without ornamentation }\end{array}$ & 22 \\
\hline
\end{tabular}

Tab. 4. The percentages of ornamental motifs in the Thin Rare-Pit Pottery group.

irregular pit (12\%), comb (22\%), framed element $(11 \%)$ and pottery without ornamentation $(27 \%)$ are the most common; and in group B, the irregular pit element (11\%), comb (52\%), grooved ornamentation $(12 \%)$ and pottery without ornamentation (12\%) were the most common. The degree of similarity between the groups is $65 \%$.

Ornamental patterns. In group A, 8 types of patterns were identified, with the comb ornamentation (56\%) and the framed ornamental elements $(26 \%)$ as the most common. In group B, 9 types of pattern were identified, among which 5 were the most common: irregular pit elements (16\%), comb (37\%), grooved $(13 \%)$, framed $(12 \%)$, and cord elements (13\%). The degree of similarity of the two groups is $67 \%$.

Ornamental motifs. Complex combined motifs predominated in both groups: 19 motifs were identified in group A and 9 motifs in group B. Complex crossed motifs were seldom used. In group A, the motif of two alternating comb patterns (26\%) is the most common, and in group B, comb patterns divided by parts without ornamentation (23\%), two alternating comb patterns (26\%), and two alternating pin patterns $(12 \%)$ were the most common. The degree of similarity between the two groups is $63 \%$.

Ornamental images. Simple and complex ornamental images were identified on the pottery of both cultural groups. The simple images dominated in each group, but they are presented by fewer variants than the complex images. Twenty-two variants of simple images were identified in group A, with the two different comb motifs (15\%) and the comb motif and zone without ornamentation (22\%) being the most common. In group B, 12 variants of simple images were identified, and 3 were applied more often: images of irregular pit and comb motifs (13\%), images of two various comb motifs (31\%), and images of comb motif and unornamented zone (17\%). The degree of similarity between the groups is $55 \%$.

In both groups, complex combined images were the most common, since 45 variants in group $A$ and 12 variants in group B were identified. Among them, the predominant images were the comb motif and motif of two alternating comb patterns (13\%) in group $\mathrm{A}$, and 5 images in group B: images including

\begin{tabular}{|l|c|c|c|}
\hline \multicolumn{2}{|c|}{ Motifs } & Group A & Group B \\
\hline pit & groove & & 14 \\
\hline pit & without ornamentation & 13 & 51 \\
\hline $\begin{array}{l}\text { irregular } \\
\text { pit }\end{array}$ & without ornamentation & 50 & 19 \\
\hline $\begin{array}{l}\text { comb } \\
\text { groove }\end{array}$ & without ornamentation & 16 & \\
\hline
\end{tabular}

Tab. 5. The percentages of simple ornamental images in the Thin Rare-Pit Pottery group.

\begin{tabular}{|c|c|c|c|}
\hline \multicolumn{2}{|r|}{ Motifs } & \multirow[t]{2}{*}{ Group A } & \multirow{2}{*}{$\begin{array}{c}\text { Group B } \\
27\end{array}$} \\
\hline $\begin{array}{l}\text { pit patterns, divided by } \\
\text { parts without ornament }\end{array}$ & without ornamentation & & \\
\hline $\begin{array}{l}\text { two alternating irregular } \\
\text { pit patterns }\end{array}$ & without ornamentation & & 13 \\
\hline pit & irregular pit patterns, divided by parts without ornamentation & 18 & 19 \\
\hline pit & two alternating irregular pit patterns & 24 & \\
\hline irregular pit & $\begin{array}{c}\text { two irregular pit patterns, divided by parts without orna } \\
\text { ornamentation ment }\end{array}$ & 28 & 13 \\
\hline $\begin{array}{l}\text { pit patterns, divided by parts } \\
\text { without ornament }\end{array}$ & pit patterns, divided by parts without ornamentation & & 13 \\
\hline $\begin{array}{l}\text { two pin patterns, divided } \\
\text { by parts without ornament }\end{array}$ & two pin patterns, divided by parts without ornamentation & & 13 \\
\hline
\end{tabular}

Tab. 6. The percentages of complex combined ornamental images in the Thin Rare-Pit Pottery group. 
Fig. 7. The Pit-and-Comb Pottery culture settlement. Group A: 1 - Core settlements: 5 Podboritsa-Zapadnaya; 8 Sadovyi Bor; 10 Panfilovskaya; 15 Fefelovskaya Pridorozhnaya; 17 Vladychinskaya-Beregovaya 1; 18 Vladychinskaya-Beregovaya 2; 20 Chernaya Gora; 23 Maslovo Boloto 2; 24 Biserovo ozero; $29 \mathrm{Za}$ rechenskaya-torfyanaya; 37 Ivanovskoe 2, SCE-1, Horizon 5; 41 Ivanovskoe 7, SCE-2, Horizon 5; 44 Pol'tso 1; 50 Nikolo-Perevoz 1; 51 Nikolo-Perevoz 2a; 52 Yazykovo 1, SCE-1, Horizon 9; 53 Yazykovo 1, SCE-2, Horizon 7; 53 a Yazykovo 1, SCE-2, Horizon 4; 59 Fedorovskaya. 2 - Peripheral settlements: 1 Gavrilovka 1; 2 Gavrilovka 2; 6 Podboritsa-Sherbininskaya; 7 Plehanov Bor; 13 Odoevskie fermy; 16a Shagara 2; 19 Vladychinskaya Borova-

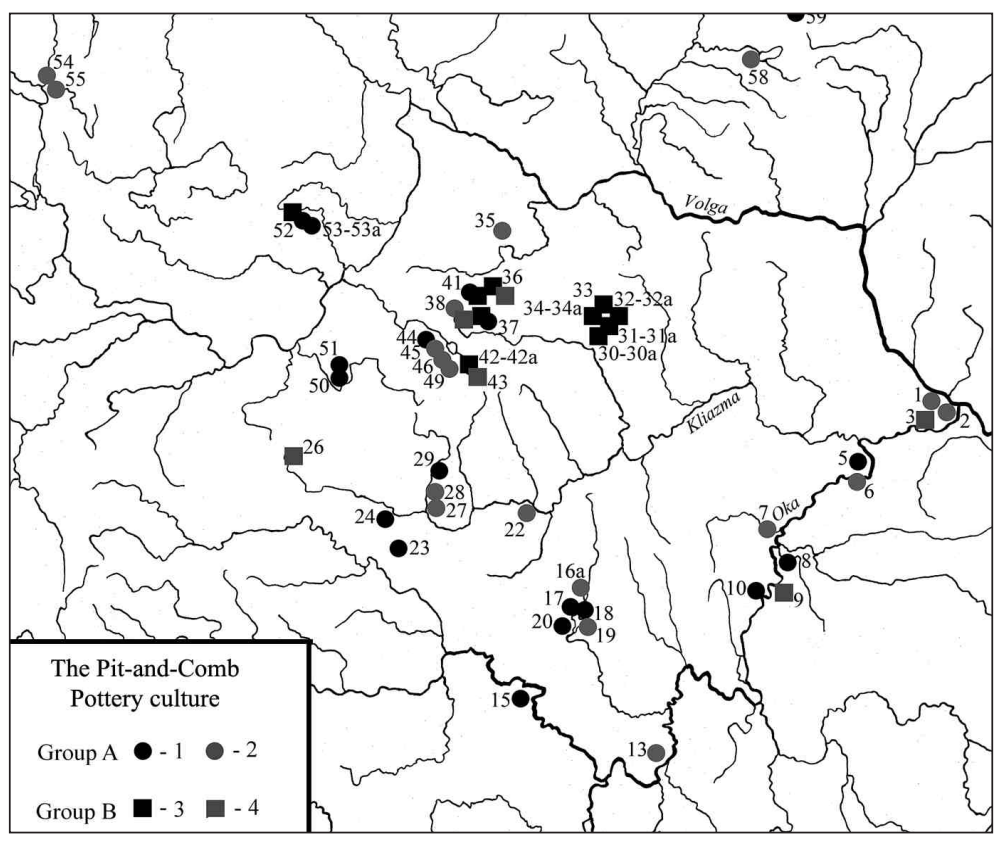
ya; 22 Bogdarnya; 27 Bol'shoe Bun'kovo; 28 Zarech'e 1; 35 Unitsa; 38 Ivanovskoe 3; SCE-1, Horizon 4; 45 Pol'tso 2; 46 Pol'tso 3; 49 Plesheevo 4; 54 - Repishe 1a; 55 Repishe 1b; 58 Umilenie. Group B: 3 - Core settlements: 30 Sahtysh 1; SCE-1, Horizon 7; 30a Sahtysh 1, SCE-1, Horizon 4; 31 Sahtysh 1, SCE-2, Horizon 6; 31a Sahtysh 1, SCE-2, Horizon 27; 32 Sahtysh 2, SCE-1, Horizon 7; 32a Sahtysh 2, SCE-1, Horizon 5; 33 Sahtysh 2, SCE-2, Horizon 19; 34 Sahtysh 8, SCE-1, Horizon 5; 34a Sahtysh 8, SCE-1, Horizon 3; 36 Vashutino 1, SCE-1, Horizon 2; 37 Ivanovskoe 2, SCE-1, Horizon 7; 41 Ivanovskoe 7, SCE-2, Horizon 3; 42 Berendeevo 1, SCE-1, Horizon 3; 42a Berendeevo 1, SCE-1, Horizon 5; 52 Yazykovo 1, SCE-1, Horizon 6. 4 - Peripheral settlements: 3 Gavrilovka 3; 9 Volosovo; 26 L'yalovo; 36 Vashutino 1, SCE-1, Horizon 5; 38 Ivanovskoe 3, SCE-1, Horizon 6; 43 Berendeevo 2a, SCE-1, Horizon 4.

motifs of two alternating comb patterns and motifs of comb pattern and parts without ornamentation $(16 \%)$; images of framed motifs and motifs of alternating comb and framed patterns (15\%); images of comb motifs and motifs of alternating pit and comb patterns (12\%); images of comb motifs and motifs of comb patterns divided by parts without ornament (11\%); and lastly, images of two motifs consisting of various alternating pin patterns (11\%). The degree of similarity between the groups is $17 \%$.

The predominant pottery group A of the Volosovo culture is characterised by more varied cultural traditions, but at the same time the recessive group B had a high number of ornamental traditions. The reasons for this phenomenon are not clear. Nevertheless, it is obvious that they due to certain processes in development of these two groups. The unity of Volosovo ornamental traditions can be seen in the high similarity of ornamental elements, patterns and motifs (63-67\%), but with a distinction in the uniqueness of ornamental images, since the degree of similarity of images is between $17-55 \%$.

We present below the results of the comparative study of ornamental traditions of the cultural groups in the population of the Upper Volga, Pit-and-Comb, and Volosovo cultures and the large groups of the populations with Rare-Pit and Thin Rare-Pit Pottery distributed on the central Russian plain. The unity of ornamental traditions within a culture is characterised by a great similarity of elements and patterns, and the specificity of the cultural groups is shown in the distinctions in complex ornamental images. Ornamental motifs and simple images occupy an intermediate position among these features. In some cultures, they heighten the unity of ornamental traditions, while in others their unity becomes weaker. For example, ornamental motifs on Thin Rare-Pit Pottery and on Volosovo culture pottery are closer in terms of cultural features, and the simple images of ornamentation play the same role for the Pit-andComb Pottery culture and for the Rare-Pit Pottery group.

As shown above, every Neolithic culture on the central Russian plain included two cultural groups with their own pottery ornamental traditions. Each of the groups included a core - sites with very similar ornamental traditions - and a periphery, which included the sites of a certain group which are characterised by considerably less similarity. Moreover, the 
sites of both groups of the same culture were not settled in a certain micro-region - some sites of both groups were grouped together in different areas of the culture's territory.

According to ethnographic sources, this core-periphery phenomenon occurred among the Tasmanians (Kabo 1986.27), the Australians (Kabo 1986. 40, 49, 55), the San/Bushmen in Africa (Kabo 1986. 140, 145), the Hadza of northern Tanzania (Kabo 1986.157), and so on. Thus, conditions when settlements of various cultural groups were grouped together could have been of short duration (for example, exhaustion of food resources, etc.), and also due to the absence of well-marked group territory, and also ties between various cultural groups. We identified the same situation in our analysis of the data on decorative stylistic traditions on the central Russian plain.

Each cultural group on the central Russian plain consisted of a cultural core that included very close relatives (probably consanguine kin) and a cultural periphery consisting of more distant relatives (perhaps affines). Let us turn to ethnographic data which present the same picture, as we can see from the Óna (a people living in Tierra del Fuego), the San/ Bushmen, the Australians (Kabo 1986.164, 166167), the Netsilik and the Polar Eskimo communities (Kabo 1986.195) and others. The core of Netsilik and Ingulik Eskimos communities included 70\% of its population (Kabo 1986.185, 193). The proportion of consanguineous kin and affines in tribal communities with unilocal exogamic marriage is about 75\% and 25\% according to A. I. Pershits (Bromley 1981.183). Thus the people in the core group are the keepers of communal cultural traditions, which is why they are more ethnically distinct. These ethnographic facts permit us to interpret the archaeological data in the same way.

According to the ethnographic classification (see Bromley 1973; Murdock 2003; White 2004) the main social and economic units of ancient society were the family, gens, community, and tribe, each of which had specific functions. The basic function of the family is reproduction and education before marriage. The main functions of the gens is in maintaining rules of marriage and relationship lines, and also in preserving the relics of the patrimonial territory, i.e., it has primarily social functions. The functions of the community are more complex: on the one hand, the community is the owner of a certain hunter-gatherer territory (economic function), while it also consists of the core (including about $70 \%$ men and women) and of affines (men under a matrilocal gens and women under a patrilocal gens). The tribe is a specific ethnic unit including numerous fractional social groups (families, gentes, and communities).

Fig. 8. The Rare-Pit pottery group settlements. Group A: 1 - Core settlements: 3 Gavrilovka 3; 13 Odoevskie fermy; 15 Fefelovskaya Pridorozhnaya; 16a Shagara 2; 20 Chernaya Gora; 30 Sahtysh 1, SCE-1, Horizon 3; 31 Sahtysh 1, SCE-2, Horizon 3; 32 Sahtysh 2, SCE-1, Horizon 6; 35 Unitsa; 36 Vashutino 1, SCE-1, Horizon 2; 36 a Vashutino 1, SCE-1, Horizon 6; 37 Ivanovskoe 2, SCE-1, Horizon 7; 37a Ivanovskoe 2, SCE-1, Horizon 6; 38 Ivanovskoe 3, SCE-1, Horizon 5; 38a Ivanovskoe 3, SCE-1, Horizon 4; 41 Ivanovskoe 7, SCE-2, Horizon 3; 42 Berendeevo 1, SCE-1, Horizon 5; 42 a Berendeevo 1, SCE-1, Horizon 3; 44 Pol'tso 1; 45 Pol'tso 2; 46 Pol'tso 3; 53 Yazykovo 1, SCE-2, Horizon 7; 53 a Yazykovo 1, SCE-2, Horizon 3; 58 Umilenie. 2 - Peripheral settlements: 7 Plehanov Bor; 18

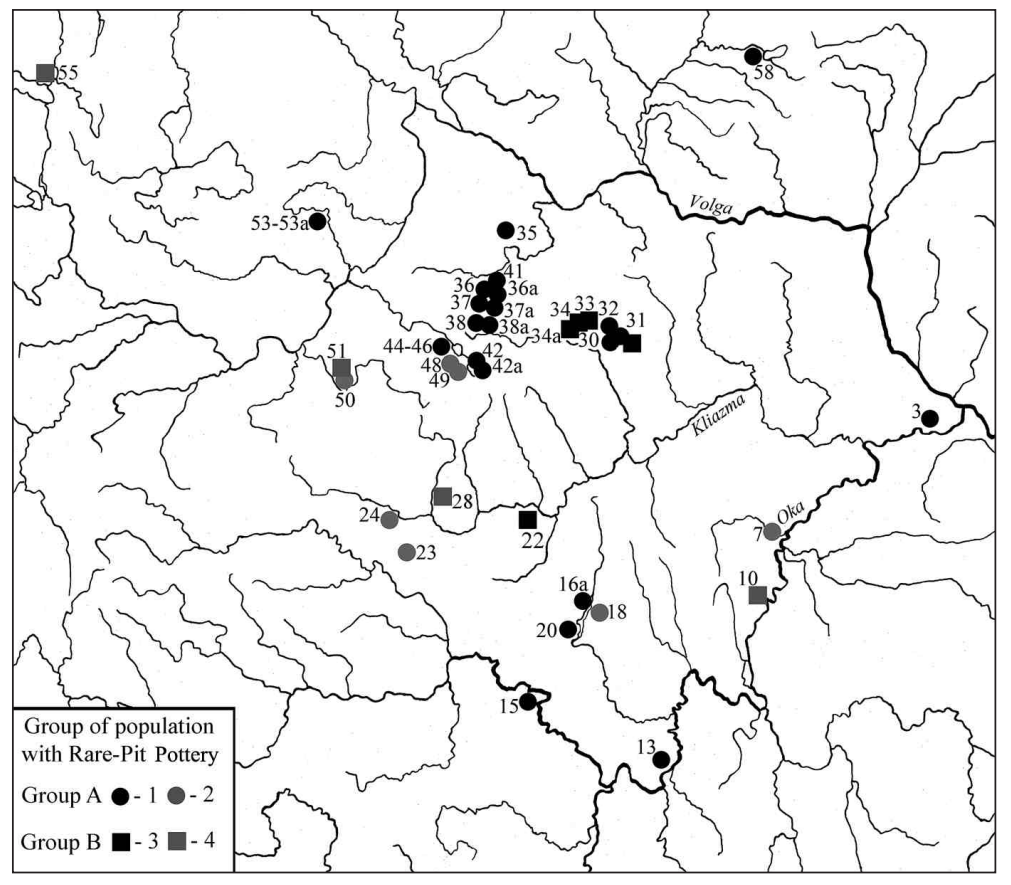
Vladychinskaya-Beregovaya 2; 23 Maslovo Boloto 2; 24 Biserovo ozero; 48 Plesheevo 2; 49 Plesheevo 4; 50 Nikolo-Perevoz 1. Group B: 3 - Core settlements: 22 Bogdarnya; 31 Sahtysh 1,SCE-2, Horizon 6; 33 Sahtysh 2, SCE-2, Horizon 19; 34 Sahtysh 8, SCE-1, Horizon 5; 34a Sahtush 8, SCE-1, Horizon 3. 4 Peripheral settlements: 10 Panfilovskaya; 28 Zarech'e 1; 51 Nikolo-Perevoz 2a; 55 Repishe 1. 
Fig. 9. The Thin Rare-Pit Pottery group settlements. Group A: 1 Core settlements: 3 Gavrilovka 3; 4 Volodary; 7 Plehanov Bor; 9 Volosovo; 13 Odoevskie fermy; 20 Chernaya Gora; 30 Sahtysh 1, SCE-1 Horizon 3; 31 Sahtysh 1, SCE-2, Horizon 3; 33 Sahtysh 2, SCE-2, Horizon 19; 34 Sahtysh 8, SCE-1 Horizon 3. 2 - Peripheral settlements: 16 a Shagara 2; 23 Maslovo Boloto 2; 31 Sahtysh 1, SCE-2, Horizon 7; 35 Unitsa; 50 Nikolo-Perevoz 1; 53 Yazykovo 1, SCE-2, Horizon 3. Group B: 3 - Core settlements: 37 Ivanovskoe 2, SCE-1, Horizon 7; 38 Ivanovskoe 3, SCE-1, Horizon 3; 38a Ivanovskoe 3, SCE-1, Horizon 5. 4 - Peripheral settlement: 15 Fefelovskaya Pridorozhnaya.

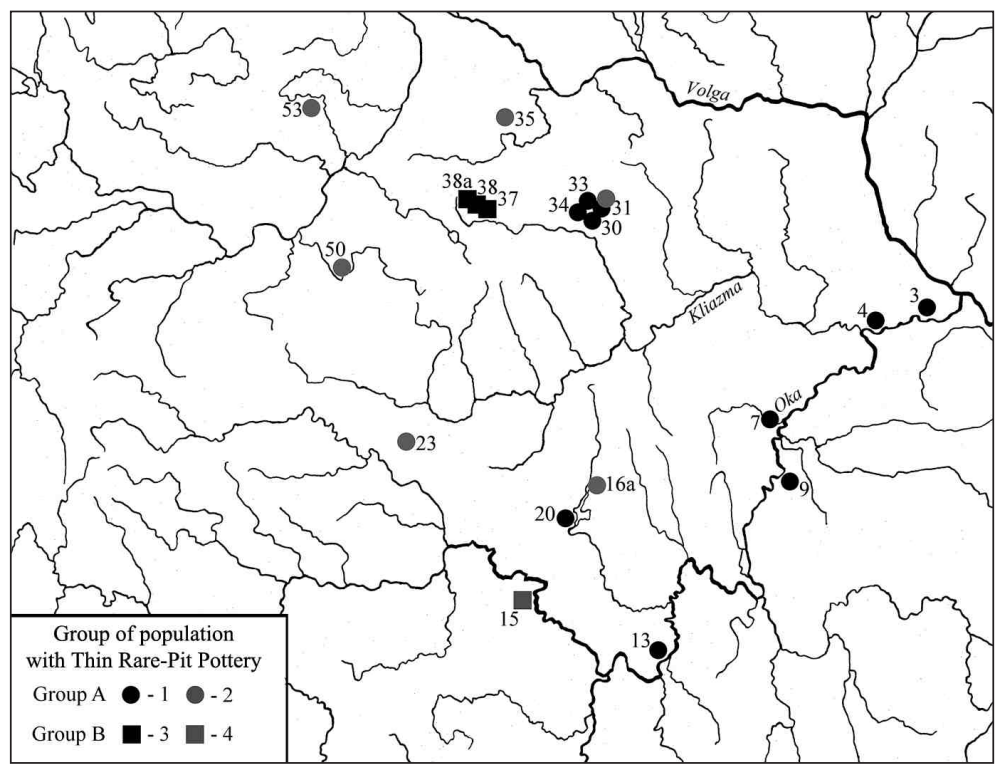

According to the data on various traditions and cultural groups on the central Russian plain, we conclude that the culture population groups overlapped, with distincitive gentes (or phratries), reflecting the dual structure of primitive tribes. As the gentes and tribal communities were usually exogamous, their settlements could not be grouped compactly within the common tribal territory, as this would hinder marriage ties between the various gentes of the tribe. According to the ethnographic data, people tried to conclude marriages with members of neighbouring gentes. This is also proven by the fact that the husband had the right to hunt in the wife's tribal community territory (Kabo 1986.54).

A comparison of the degree of similarity of elements of cultural ornamental traditions between coexisting cultures and between the patrimonial groups within

Fig. 10. The Volosovo pottery group settlements. Group A: 1 - Core settlements: 1Gavrilovka 1; 3 Gavrilovka 3; 4 Volodary; 5 PodboritsaZapadnaya; 6 Podboritsa-Sherbininskaya; 7 Plehanov Bor; 9 Volosovo; 10 Panfilovskaya; 11 Iberdus 1; 13 Odoevskie fermy; 16a Shagara 2; 17 Vladychinskaya Beregovaya 1; 20 Chernaya Gora; 28 Zarech'e 1; 31Sahtysh 1, SCE-2, Horizon 4; 34 Sahtysh 8, SCE-1, Horizon 5; 34a Sahtysh 8, SCE-1, Horizon 3; 38 Ivanovskoe 3, SCE-1, Horizon 3; 38 a Ivanovskoe 3, SCE-1, Horizon 5; 50 Nikolo-Perevoz 1; 53 Yazykovo 1, SCE-2, Horizon 3; 53 a Yazykovo 1, SCE-2, Horizon 5. 2 Peripheral settlements: 15 Fefelovskaya Pridorozhnaya; 18 Vladychinskaya-Beregovaya 2; 23 Maslovo Boloto 2; 31 Sahtysh 1, SCE-2, Horizon 6; 32 Sahtysh 2, SCE-1,

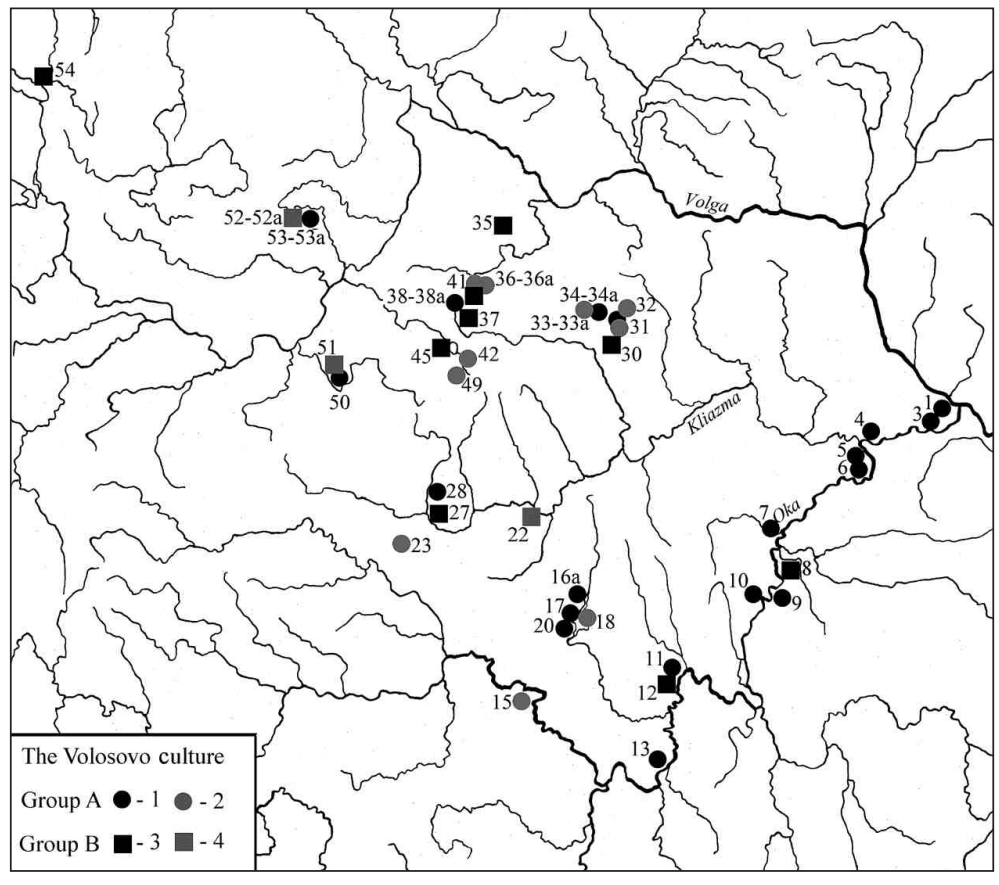
Horizon 5; 33 Sahtysh 2, SCE-2, Horizon 13; 33a Sahtysh 2, SCE-2, Horizon 17; 36 Vashutino 1, SCE-1, Horizon 4; 36 a Vashutino 1, SCE-1, Horizon 2; 41 Ivanovskoe 7, SCE-2, Horizon 3; 42 Berendeevo 1, SCE-1, Horizon 3; 49 Plesheevo 4. Group B: 3 - Core settlements: 8 Sadovyi Bor; 12 Iberdus 2; 27 Bol'shoe Bun'kovo; 30 Sahtysh 1, SCE-1, Horizon 4; 35 Unitsa; 37 Ivanovskoe 2, SCE-1, Horizon 7; 41 Ivanovskoe 7, SCE-2, Horizon 5; 45 Pol'tso 2; 54 Repishe 1. 4 - Peripheral settlements: 22 Bogdarnya; 51 Nikolo-Perevoz 2a; 52 Yazykovo 1, SCE-1, Horizon 7; 52 a Yazykovo 1, SCE-1, Horizon 2. 


\begin{tabular}{|l|c|c|c|}
\hline Connections between cultures/groups & Similarity (in \%) & $\begin{array}{c}\text { Connections between gentes } \\
\text { groups within cultures/groups }\end{array}$ & Similarity (in \%) \\
\hline Upper Volga culture vs. Pit-and-Comb culture & 48.8 & Upper Volga culture & 65.0 \\
\hline Pit-and-Comb culture vs. Rare-Pit group & 55.6 & Pit-and-Comb culture & 76.0 \\
\hline Pit-and-Comb culture vs. Thin Rare-Pit group & 50.1 & Rare-Pit group & 74.0 \\
\hline Pit-and-Comb culture vs. Volosovo culture & 44.8 & Thin Rare-Pit group & 53.0 \\
\hline Rare-Pit group vs. Thin Rare-Pit group & 72.8 & Volosovo culture & 65.0 \\
\hline Rare-Pit group vs. Volosovo culture & 48.8 & & \\
\hline Thin Rare-Pit group vs. Volosovo culture & 53.2 & & \\
\hline
\end{tabular}

Tab. 7. The percentages of similarity between co-existing cultures and between gentes groups within them according to ornamental traditions.

them yields further information (Tab. 7). Judging by this data, the similarity of ornamental traditions of various archaeological cultures is lower than the similarity of traditions between patrimonial groups within each culture, with one exception, in the similarity of traditions between the Rare-Pit and the Thin Rare-Pit Pottery groups (72.8\%). This is not surprising, since the status of these groups is not quite clear yet.
Thus, we conclude that most of the Neolithic cultures on the central Russian plain reflect endogamous tribal organisations, each of which included two patrimonial (or phratrial) population groups with specific features in their pottery decoration traditions.

\section{References}

Bromley Y. V. 1973. Ethnos and Ethnography. Nauka Press. Moscow. (In Russian)

1981. Recent Ethnographical Problems (Studies of theory and history). Nauka Press. Moscow. (In Russian)

Kabo V. R. 1986. Pervobytnaia dozemledelcheskaia obshina (Primitive community before farming). Nauka Press. Moscow. (In Russian)
Murdock G. 2003. Social Structure. Moscow. OGI Press. 2003. (In Russian)

White L. 2004. The Evolution of Culture - The development of civilisation before the fall of Rome. In L. White Selected works: Evolution of Culture. ROSSPEN. Moscow. (In Russian)

Tsetlin Y. B. 2008. The Center of the Russian Plain in the Neolithic Age. Decoration of Clay Vessels and Methods for the Periodization of Cultures. Institute of Archaeology. Tula. (In Russian) 